\title{
Pluridisciplinary analysis and multi-archive reconstruction of paleofloods: societal demand, challenges and progress
}

3

\author{
Lothar Schulte $^{1}$, Daniel Schillereff ${ }^{2}$, Juan Ignacio Santisteban ${ }^{3}$ \\ ${ }^{1}$ FluvAlps Research Group, Department of Geography, University of Barcelona, Spain, \\ schulte@ub.edu \\ ${ }^{2}$ Department of Geography, King's College London, United Kingdom, \\ daniel.schillereff@kcl.ac.uk \\ ${ }^{3}$ Department of Geodynamics, Stratigraphy and Paleontology, Fac. of Geological Sciences, \\ Complutense University of Madrid, Spain, j.i.santisteban@geo.ucm.es \\ Corresponding author: Lothar Schulte, schulte@ub.edu
}

\section{Abstract.}

Floods are one of the gravest natural hazards for societies, worsened by population growth, unchecked development, and climate change. From a Global Change perspective, past extreme events merit particular interest because they can be linked to wider climate and environmental changes, introduce perturbations. During the last decade, knowledge of long-term flood frequency and magnitude has been improved by extracting data from different types of archive. But, despite advances in dating methods, proxies and statistical techniques and efforts to identify atmospheric drivers, some fundamental questions remain unresolved. The Special Issue entitled "Pluridisciplinary analysis and multi-archive reconstruction of paleofloods" in the journal Global and Planetary Change addresses these uncertainties and complexities by assembling a selection of studies, which were first presented at the Past Climate Changes (PAGES) Open Scientific Meeting held at Zaragoza in 2017. In this introductory 
paper, the guest editors outline the 17 research contributions and meta-data from the 17 paleoflood studies were systematically analyzed in terms of i) geographical distribution; ii) methodologies applied; iii) types of archives; iii) numbers of flood series compiled and iv) spatial and temporal resolution of paleoflood data. The data indicate that paleoflood studies focused on fluvial depositional environments show a higher rate of integration with other types of paleoflood archive (mean of 4.5 types of archive) than studies focused on documentary sources (mean of 3.5) and lake sediments (mean of 2.4). We suggest that this strategy of archive integration has been adapted to effectively compensate for the higher uncertainties of fluvial deposition in floodplains. Statistical processing of the meta-data shows quantitative associations between specific types of flood archive and offers a solid platform for designing the optimal approach for multiarchive paleoflood research. A qualitative review and visual comparison of the 17 paleoflood series shows some consistent trends and breaks but also notable differences within and between regions. While a trend of increased flooding since 4-5 ka BP is evident, the lack of synchronicity between breaks and the coeval increases and decreases in fluvial activity is manifest. The majority of studies in the Special Issue do denote the $19^{\text {th }}$ century - including the youngest cool climate pulses during the Little Ice Age - as a particularly flood-rich period. It is more difficult to assess the $20^{\text {th }}$ century because of social changes, population growth and extensive river modification. Despite the mentioned uncertainties, 10 of 14 papers do not record the $20^{\text {th }}$ century as an exceptional flood period. Assessing the effects of human impact on paleoflood calendars and disentangling anthropogenic from natural drivers are major challenges in integrated paleoflood analysis. 
52 It is concluded that the interpretation of flood series is complex as landscapes and flood drivers are heterogeneous and systems show different sensitivities to flood control and drivers. Thus, the study of past floods, from historical and natural archives, is challenging but also offers unparalleled opportunities to document low-frequency, large-magnitude flood events, which occurred under a broad range of climate and/or environmental scenarios, and, probably, the only way to reconstruct robust paleoflood series.

Keywords: Paleoflood hydrology; flood hazard; natural archives; documentary sources; multi-archive reconstruction; integration model.

\section{The motivation of this Special Issue}

The integration of multi-archive flood proxies to reconstruct flooding hundreds or thousands of years ago is like putting together a puzzle. In the beginning, the numerous pieces appear chaotic and confusing. But after struggling for some years or even decades, structure and eventually a diffuse picture becomes recognizable. This differs from an ordinary puzzle, however, because the number of pieces is not finite and the puzzle will never be finished. Although this might produce at a first glance a certain frustration, there are many other aspects which fully satisfy the expectations of scientists.

The first aspect is that the development of multi-archive flood records is a relatively modern approach. Over the last two decades, a growing number of studies have reconstructed flood records spanning centuries and millennia from fluvial sediments, lake deposits, speleothems or tree-rings (Baker, 1987; Benito et al., 2004; Schulte et al., 2008, 2009b; Wilhelm et al., 2012; 2019; Díez-Herrero 
et al., 2013; Wirth et al., 2013, Schillereff et al., 2014; Ballesteros-Cánovas et al., 2014; Santisteban et al., 2017; Denniston and Lütscher, 2017). These data series were largely confined to comparisons of paleoflood series with historical sources and instrumental measurement of discharge and precipitation. More recently, efforts were made to depict flood patterns across larger regions based on instrumental data covering half a century (Blöschel et al., 2017). At the same time, historians and geographers produced regional compilations also from historical sources (e.g. Röthlisberger, 1991; Glaser, 2001; Brázdil et al., 2005a, 2005b; Wetter, 2011; Macdonald and Sangster, 2017; Paprotny et al., 2018). Historical records and long instrumental records are mostly restricted to larger river towns (Pfister, 1999; Barriendos et al., 2014; Elleder et al., 2015; Wetter, 2017) whereas catchments in more remote regions, particularly mountain basins, are often ungauged and historical sources may be scarce (Schulte et al., 2009a, 2015). Since flood archives are embedded in different geographical and environmental settings, and their "perfect" study sites do not coincide geographically, paleoflood information is often fragmented.

Multi-proxy approaches have become standard in paleoenvironmental and paleoflood research (Santisteban et al., 2017; Wilhelm et al., 2019), whereas multi-archive studies in sensu strictu which integrate more than three different types of flood archives are extremely rare (Schulte et al., 2015). This presents opportunities for creative researchers to open doors to a fascinating world where they can explore, combine, disentangle and test several combinations of flood archives.

A second motivation is the attraction of multi-disciplinary research. It is exciting to meet researchers from other fields at conferences, workshops, field 
excursions, or on interdisciplinary field work and listen to them describe their approaches to researching floods. It is remarkable that they all look at the same physical process but use other archives, proxies, markers, thresholds and so on. For example, who could imagine that bioindicators such as algae and lichens in $\mathrm{cm}$-small alveoli in canyon rock walls could provide information about floods? Therefore, it is vital for the paleoflood community to test reconstructed past floods through different techniques, methods, and scientific views.

A third aspect is the spatial dimension of the flood phenomenon. Different archives allow flood information to be obtained that better reflects the diversity of landscapes that experience flooding compared to studies that focus on only one type of archive. For example, in mountain regions, flood information can be obtained from high-altitude lakes, tree-rings and lichen colonization of river banks, gorge rock surfaces, and alluvial fan deposits at mid-altitudes, and from low-altitude floodplains and deltas (alluvial sediments, historical and archaeological evidence, pollen, etc.). In some basins, flood data can be obtained from multiple sites that differ in elevation by $1500 \mathrm{~m}$ or more within only a few kilometers (Schulte et al., this issue; Zaginaev et al., this issue). Another promising approach is the reconstruction of single flood events in terms of total flooded area, the propagation of the flood wave and the path of the precipitation field (Kiss, 2009; Elleder et al., this issue). Furthermore, where a high density of paleohydrological data is available, the production of paleoflood maps can improve our spatial understanding of flood dynamics (Röthlisberger, 1991; Schmocker-Fackel and Naef, 2010; Barriendos et al., this issue; Schulte et al., this issue). In this context, a further methodological innovation is the reconstruction, reanalysis and modelling of synoptic sea level pressure maps of 
extreme flood episodes, which improve our knowledge about atmospheric variability as a flood driver (Ortega et al., this issue; Peña and Schulte, this issue; Sánchez-García et al., this issue, Schulte et al., this issue).

\section{Foci of the PAGES Floods Working Group}

The exposed range of opportunities is one of the reasons why multidisciplinary analysis and multi-archive reconstruction of paleofloods define one of the three core activities of the Past Climate Changes (PAGES) Floods Working Group since its founding in 2015. According to the White Paper (PAGES - Floods Working Group, 2017), the Working Group "aims to bring together all the scientific communities reconstructing past floods (historians, geologists, geographers, etc.) and those studying current and future floods (hydrologists, modelers, statisticians, etc.) to coordinate, synthesize and promote data and results on the natural variability of floods". Also in 2017, the Floods Working Group launched three work packages (WP): WP1 focuses on collecting, storing and sharing of global paleoflood data, WP2 on integrating and analyzing paleoflood data and WP3 on communicating and disseminating paleoflood science and data at different levels, including stakeholders. Conference sessions of the WP2 topic were organized in 2016 during the first Floods Working Group Workshop in Grenoble and in 2017 on the PAGES Open Scientific Meeting held at Zaragoza. Also in 2016 several members of WP2 launched a pilot project of paleoflood data integration in the Swiss Alps. The results of the first phase of this research of geographers, historians, geologists, and geochemists are presented in the paper of Schulte et al. entitled "Integration of multi-archive datasets towards the development of a four-dimensional paleoflood model in alpine catchments" in this 
151 Special Issue. These research activities will continue during the second phase

152 (2019-2021) of the FWG Program.

\section{Societal demand for multi-archive reconstruction of paleofloods}

Floods are one of the gravest natural hazards for societies, worsened by population growth, unchecked development and climate change (UNISDR, 2015). So, the transfer of long flood series to public agencies is crucial for producing reliable evaluations of floods and societal risk. However, although policies have been developed (e.g. Directive 2007/60/EC of the European Parliament and of the Council of 23 October 2007 on the assessment and management of flood risks; Real Decreto 903/2010, of July $9^{\text {th }}$, Assessment and management of floods), the integration of paleoflood studies into spatial planning and flood risk assessment is not sufficiently applied. From a Global Change perspective (Baker, 2006), past extreme events are of interest as they can be linked to climate and environmental changes, introduce perturbations in natural systems and can be traced in paleoenvironmental archives. Hence, paleoflood research is a rapidly developing approach through which insight from multiple disciplines (hydrology, geomorphology, climatology, paleolimnology) has implications for human life as its goal is to understand and quantify flood risk over extended periods of time.

During the last decade, knowledge of flood frequency and magnitude has improved through data coming from different types of archives (Baker, 1987; Benito et al., 2004; Schulte et al., 2015; Schillereff et al., 2016; Wilhelm et al., 2019). But, despite advances in dating methods, proxies and statistical techniques and efforts to identify atmospheric drivers, some fundamental 
questions remain unresolved. The interpretation of flood series is complex as landscapes and flood drivers are heterogeneous and systems show different sensitivities to hydrometeorological forcings. Thus, the study of past floods using historical and natural archives is challenging but also a rare opportunity to document low-frequency, large-magnitude flood events. Long-term studies also allow trends in flooding that occurred under a broad range of climate and/or environmental scenarios to be explored, which is probably the only way to reconstruct robust paleoflood series. This issue addresses these uncertainties and complexities by assembling a selection of studies with a global geographical distribution (high to low latitude, from mountains to lowlands) and provide an insight about present state on multi-source data (lakes, floodplains, geomorphology, tree-rings, historical and archaeological sources, soils, marine sediments, etc.), controls/drivers and time-scales integration (from Pleistocene to present time) plus methodological and societal issues in paleoflood research.

\section{Contents of contributions to multi-archive paleoflood reconstruction}

The compilation of this Special Issue, which includes 17 research papers, is the outcome of the PAGES OSM Conference session entitled "Multidisciplinary reconstruction of paleofloods". Sixteen oral contributions and 18 posters from most continents were presented and lively discussed. The papers showcase substantial progress in the analysis and interpretation of flood archives, important methodological advancements, including innovative approaches to integrate and model diverse archives and flood series, and a focus on remote regions with difficult access. 
The research papers of Santisteban et al. (this issue) and Fuller et al. (this issue) are case studies from Central Spain and New Zealand that demonstrate how high-resolution, continuous geochemical flood proxies can be inferred from alluvial sediments that span most of the Holocene. Santisteban et al. (this issue) use several geochemical ratios as proxies for water competence, water level, and sediment discharge to reconstruct flood pulses. Similarly, Fuller et al. (this issue) estimated the flood recurrence interval using normalized $\mathrm{Zr} / \mathrm{Rb}$ measurements and a tight age-depth model in a volcanically-reset catchment.

The studies of Agatova et al. (this issue) and Lombardo et al. (this issue) focus on large-scale flood areas in Asia and South America which are difficult to access. In south-western Amazonia, Lombardo et al. (this issue) combined proxies such as phytoliths and stable carbon isotopes from sedimentary flood archives and soils to provide a solid reconstruction of past Holocene land cover change and periods of low or modest flooding. Agatova et al. (this issue) used geomorphological, geological and geoarchaeological data to reconstruct the presence of Late Pleistocene ice-dammed lakes and cataclysmic outburst floods in the Mongolian Inland Drainage Basin. A multi-century dataset of regional 217 glacial outburst floods (GLOF) is presented by Zaginaev et al. for the Tien Shan 218 (Central Asia). These high discharge flash-floods were reconstructed by tree-ring analyses from six different torrential fans providing insights on regional process activity.

A different approach is adopted by the following four papers: extracting evidence from documentary archives to produce regional centennial flood series. Barriendos et al. (this issue) provide 18 extensive flood event chronologies for the Spanish Mediterranean coast from $14^{\text {th }}$ to $20^{\text {th }}$ centuries. They discuss the 
225 profound influence of social factors on historical flood data series and evaluate

226 methods of integrating multi-source information such as population and flood

227 protection measures. This human component also affects the 450-year reconstruction of historical discharges performed by Sánchez-García et al. (this issue) from semi-arid South-eastern Spain. Furthermore, the synoptic atmospheric configurations of four catastrophic flood events were investigated. In the River Jing catchment, southern Chinese Loess Plateau, Yu et al. (this issue) identified decadal solar activities as an important driver for floods and droughts. Multiple documentary sources and a precipitation-runoff model were used by Elleder et al. (this issue) to explore the spatial imprint of the 1872 flashflood in central Bohemia and model the river's runoff response.

Another five papers deal with paleoflood reconstruction and flood frequency analysis using lake records. Evin et al. (this issue) propose a novel statistical approach that combines a classic series of paleoflood observations for the Rhône River reconstructed from lake sediments (Lake Bourget, Northwestern Alps, France) and disseminates uncertainties related to the reconstruction method during the estimation of extreme quantiles. Albrecher et al. (this issue) applied a change-point analysis to sedimentary flood frequency data from six large alpine lakes. This enabled a comparison to be made with other flood records and possible links to be drawn between event frequencies and climatic conditions. Corella et al. (this issue) present a new method for estimating seasonallyresolved flood erosion rates using millennium-long varved lake sediments. Their use of high-precision, multi-proxy data also sheds light on the main environmental drivers (climatic or anthropogenic) controlling sediment yield in a mountainous 
250 Holocene flood frequency were also investigated by Rapuc et al. (this issue) in 251 Lake Iseo (Southern Alps). Similarly, Schillereff et al. (this issue) showed that detailed sub-sampling and proxy analysis based on particle size data, coupled with careful evaluation against independent hydrological data and accounting for variations in external sediment supply potentially driven by anthropogenic landscape modification, is an appropriate methodology to extract paleoflood records from temperate lakes.

To explore climatic forcing of floods Peña and Schulte (this issue) performed a paleoclimate modeling experiment of the atmospheric variability related to large summer floods in the Hasli-Aare (Swiss Alps) from the AD 1300 to 2010. They propose the name of paleo-SNAO to define this decadal atmospheric variability related to summer floods in the alpine catchment.

Schulte et al. (this issue) designed an innovative methodology that integrates multi-archive datasets towards the development of a spatial-temporal (fourdimensional) paleoflood model in alpine catchments. The most continuous and accurate series from natural and anthropogenic flood archives were integrated over the period from AD 1400 to 2005 into a synthetic flood master curve for the Bernese Alps.

Ortega et al. (this issue) analyzed extreme ENSO-driven torrential rainfalls at the southern edge of the Atacama Desert during the Late Holocene and their projection into the $21^{\text {st }}$ century. The integration of marine paleoclimate proxies, historical data, and the future projection helps to understand oceanic and climatic factors conditioning the variability of extreme rainfall events. 

geographical distribution (four continents, northern and southern hemisphere;

277 Figure 1); ii) types of paleoflood archives; iii) numbers of flood series compiled; iv) spatial and temporal resolution and v) methodologies applied for the integration of flood data (Table 1).

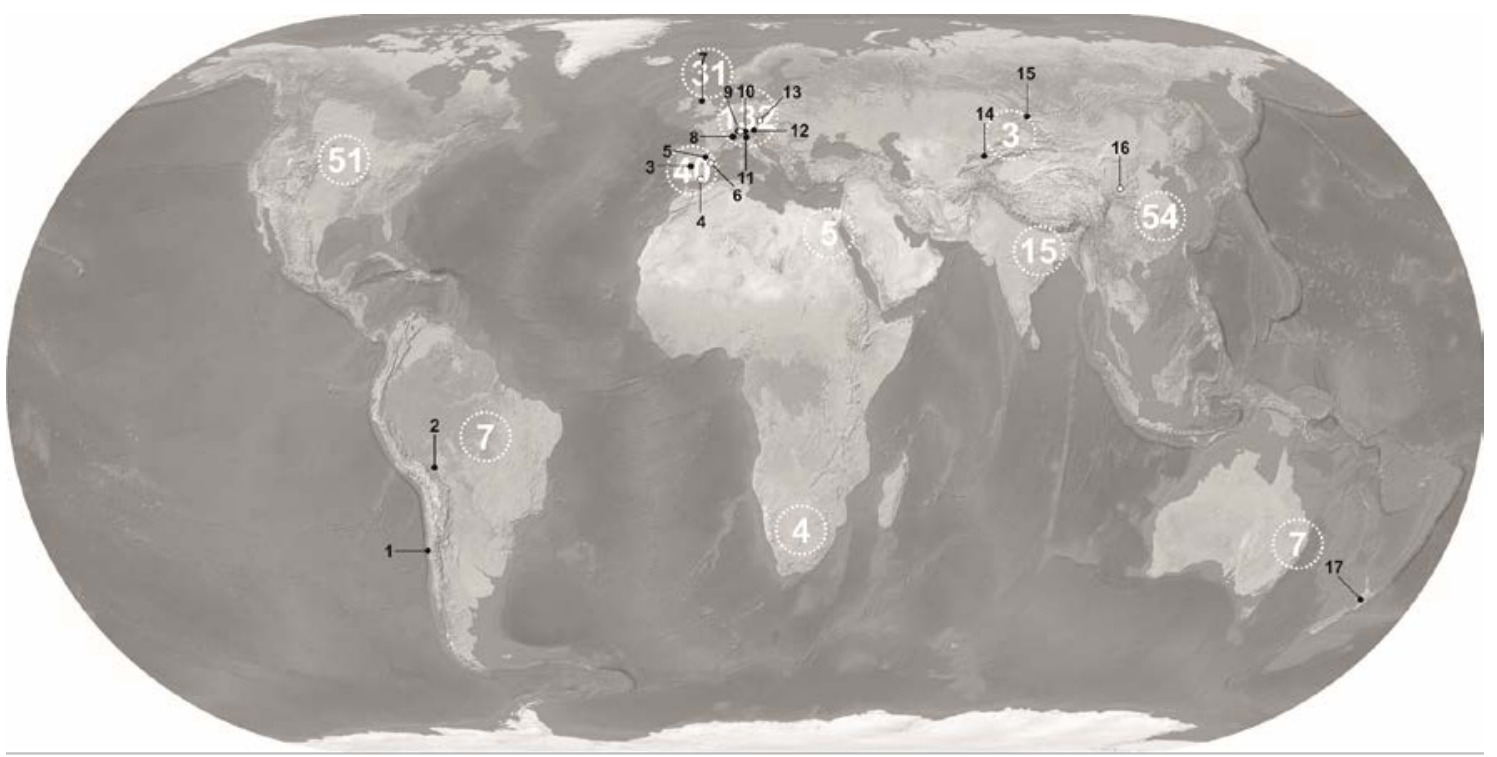

1- Flood records mainly from natural archives

$4 \longrightarrow$ Mainly from documentary archives

9 - From natural and documentary archives

3. Number of flood series FWG metadatabase

Figure 1. Location of the case studies (black numbers) presented in the research papers of this Special Issue. The ID of each paper is listed in Table 1. White numbers encircled presents the number of studies recorded in the paleoflood metadatabase of the PAGES Floods Working Group for each region (PAGES-FWG, http://www.pages-igbp.org/ini/wg/floods/wp1/data, date of access

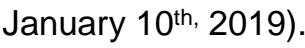

287 Figure 1 reflects two types of data: the papers presented in this Special Issue (black numbers) and the regional distribution of studies recorded in the paleoflood metadatabase of the PAGES Floods Working Group (FWG; http://www.pagesigbp.org/ini/wg/floods/wp1/data, white circled numbers). More than half of the 
studies archived in the FWG databank are located in Europe. More than 50 studies were carried out in North America as well as in China, 15 in India, whereas low numbers are recorded in Australia/New Zealand, Central Asia, Africa, and South America. $36 \%$ of these records were obtained from historical documents, $33 \%$ from riverine sediments, $29 \%$ from studies of lake sediments and tree rings and, finally 2\% from speleothems (PAGES Floods Working Group, 2019). These works but may reflect some general trends. The high numbers obtained in Europe reflect the intense research activities in the field of paleoflood reconstruction across the continent, but, on the other hand, these numbers are also influenced by the location of organized workshops and annual meetings, the hosting of the

PAGES office and members of the FWG steering committee and the lower level of cooperation with researchers from other continents. For example, in recent years several European researchers (many active in the FWG network) attended paleoflood conferences organized by US researchers (e.g. Rapid City 2016) and vice versa, but no joint conference has yet been organized by both communities. The paleoflood community is in a similar situation with regard to links with Asia.

In addition to the innovative topics and methodological progress of the presented research papers, the metadata of these case studies presented in Table 1 provides interesting insight into the structure of multi-archive paleoflood approaches. According to Table 1 and Figure 3, the papers presented in this environments and landscapes; the second group reconstructs flood calendars special issue can be subdivided into different groups. The first group includes papers which present flood series from alluvial and fluvial depositional from historical sources, and the third investigates past floods from lake deposits. 
316 Finally, there are contributions that focus on flood records from tree-rings and 317 marine sediments or integrate numerous types of flood archives. 


\begin{tabular}{|c|c|c|c|c|c|c|c|c|c|c|c|c|}
\hline $\begin{array}{l}\frac{\mathrm{a}}{\mathrm{o}} \\
\frac{\mathrm{o}}{2}\end{array}$ & 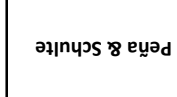 & 이 & 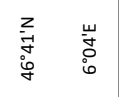 & ○. & & & -7 & & & $r$ & 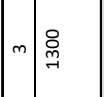 & 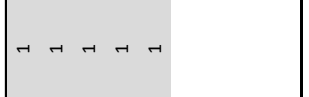 \\
\hline 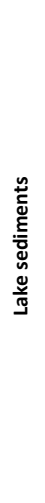 & 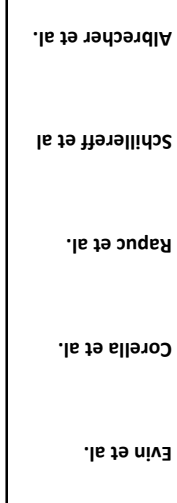 & $=$ & 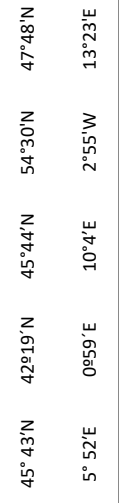 & $\mid$ & & 7 & $\Xi$ & $\Xi$ & 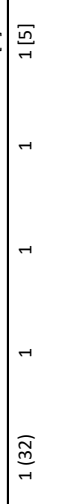 & - & 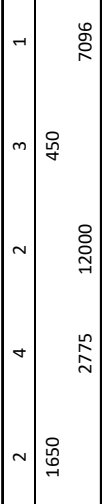 & 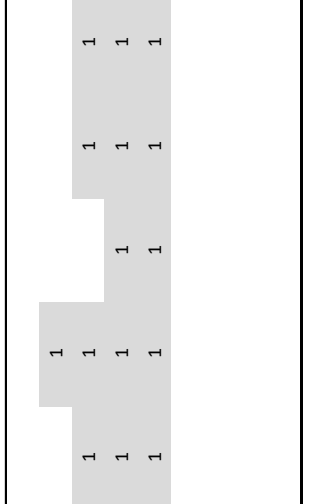 \\
\hline 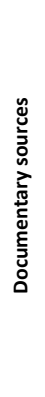 & 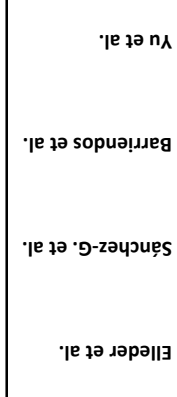 & + & 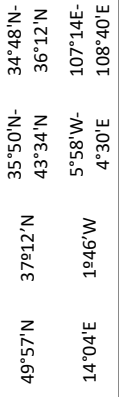 & 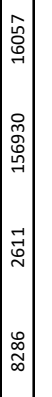 & & & 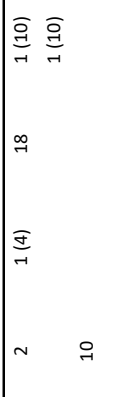 & $\sim m$ & & $\rightarrow$ & م| & 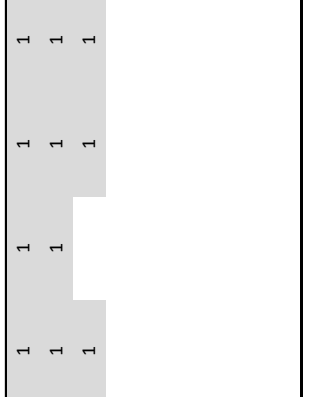 \\
\hline 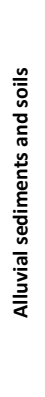 & 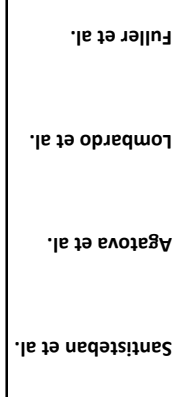 & $\begin{array}{l}= \\
= \\
\sim\end{array}$ & 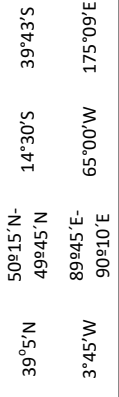 & 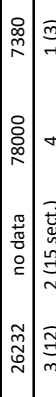 & 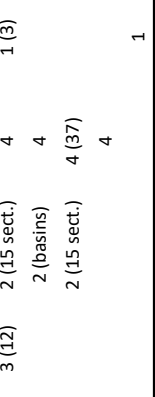 & & $\begin{array}{ll}a & -1\end{array}$ & $\Xi+$ & & - & 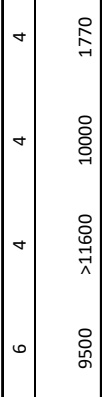 & 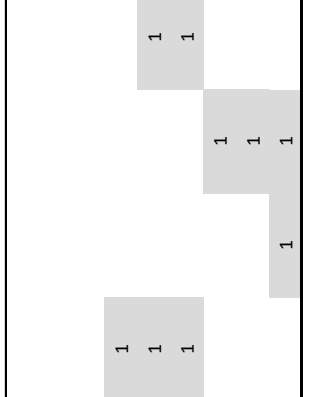 \\
\hline 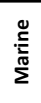 & ס & 4 & 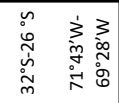 & 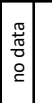 & & & - & - & - & 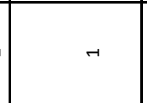 & $\nabla$ 苛 & -4 \\
\hline 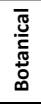 & 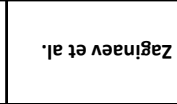 & $\mp$ & 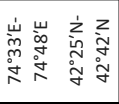 & 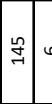 & 。 & 。 & 0 & & & $\circ$ & 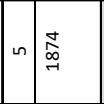 & $4 t^{4}$ \\
\hline$\frac{\bar{T}}{2}$ & 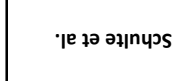 & 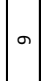 & 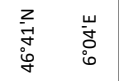 & $\hat{\mathrm{N}}$ & $+m+m$ & $+\Xi \Xi$ & $0 \quad \Xi-$ & $\Xi \wedge$ & + & $\Xi+\Xi$ & $\Rightarrow$ 夆 & $y t a t h$ \\
\hline & 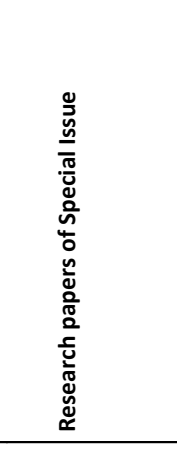 & 总 & 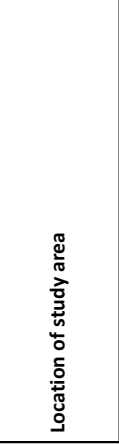 & 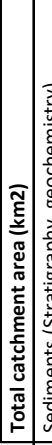 & 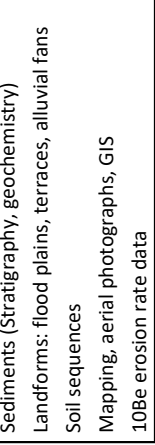 & 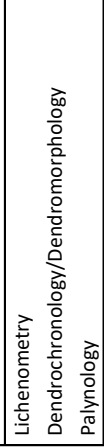 & 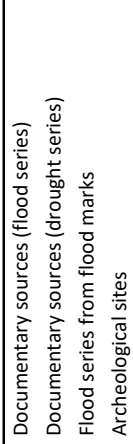 & 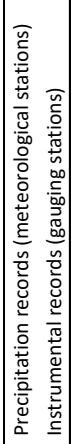 & 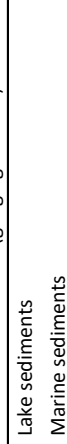 & 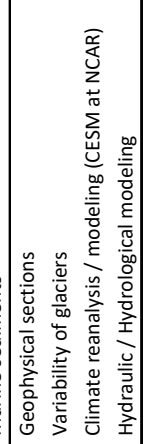 & 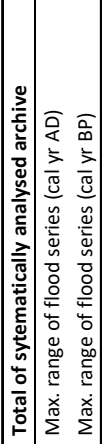 & 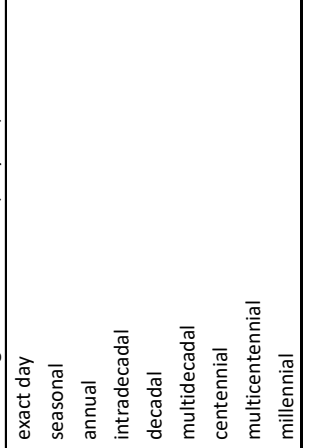 \\
\hline \multicolumn{5}{|c|}{ еұер еұәш ગ̣seg } & \multicolumn{6}{|c|}{ 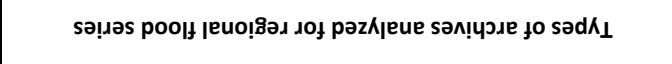 } & am!1 & 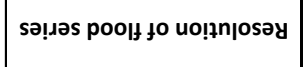 \\
\hline
\end{tabular}


Table 1: Metadata of Paleoflood case studies published in the Special Issue. A) Numbers of different types of archive analyzed to compile regional flood series. Legend: $2=$ number of analyzed flood series (one series per type of archive and catchment, region or area). If data is available: (2) = number of records; [1] = punctual data record or data not explicitly discussed in paper

The number of systematically analyzed types of flood archives listed in Table 1 varies significantly between papers. Seven studies - primarily investigating historical sources and lake sediments - draw on one to three types of archives; nine papers incorporate four to six types of archive and one paper utilizes up to ten. The meta-data indicates that paleoflood studies focused on fluvial depositional environments show a higher rate of integration of different types of paleoflood archives (mean of 4.5 types of archives) than studies focused on documentary sources (mean of 3.5) and lake sediments (mean of 2.4).

Papers in this Special Issue present paleoflood reconstructions over variable time periods, ranging from one and a half centuries (tree rings; Zaginaev et al., this issue) to the Early Holocene (lake and alluvial flood records; Rapuc et al., this issue; Santisteban et al., this issue) while the reconstruction of catastrophic floods from the Mongolian Great Lakes Basin reaches back to the Late Pleistocene (Agatova et al., this issue). The highest temporal resolution (exact dates, seasonal and annual flood information) were obtained by studies using documentary sources or papers that combine natural flood archives (e.g. tree rings and varved lake sediments) with documentary and instrumental data. It is striking that most approaches exploiting natural archives (except soils and fluvial landforms) achieve a temporal accuracy of decadal or better. 
345 With regard to the spatial scale, large differences in the size of study areas and catchments are noticeable in Table 1 . Catchments smaller than $100 \mathrm{~km}^{2}$ are associated with lake reconstructions, whereas larger areas of more than 50,000 $\mathrm{km}^{2}$ were studied by papers focused on landscape, landform and soil development. Barriendos et al. (this issue) submitted the paper with a total area of $156,930 \mathrm{~km}^{2}$, which presents documentary flood records from 18 catchments spanning the Mediterranean slope of the Iberian Peninsula.

\section{How are paleoflood archives combined and integrated?}

A possibility to develop a conceptual framework for multiple-archive paleoflood integration is the performance of a qualitative approach (PAGES - Floods Working Group, 2017). However, statistical processing of the meta-data from paleoflood studies published in this Special Issue could provide valuable insight. This testing shows associations between different types of flood archive, achieving a solid background for the design of an integrated multi-archive paleoflood approach.

The variables (number of flood archive types analyzed for generating paleoflood series) presented in Table 1 were transformed into a binary system and introduced into a matrix. Factor analysis (FA) was performed to explore the variability of flood archives across the 17 studies. Figure 2 shows the 2 dimensional plot of the first two factors explaining 34\% (F1) and 19\% (F2) of the variability. The following groups are identified: (i) fluvial and terrestrial archives (red circle); (ii) botanical archives (green circle); hydrological archives (light blue circle) and (iv) precipitation, discharge measurements and documentary sources 

sediments show a more scattered distribution.

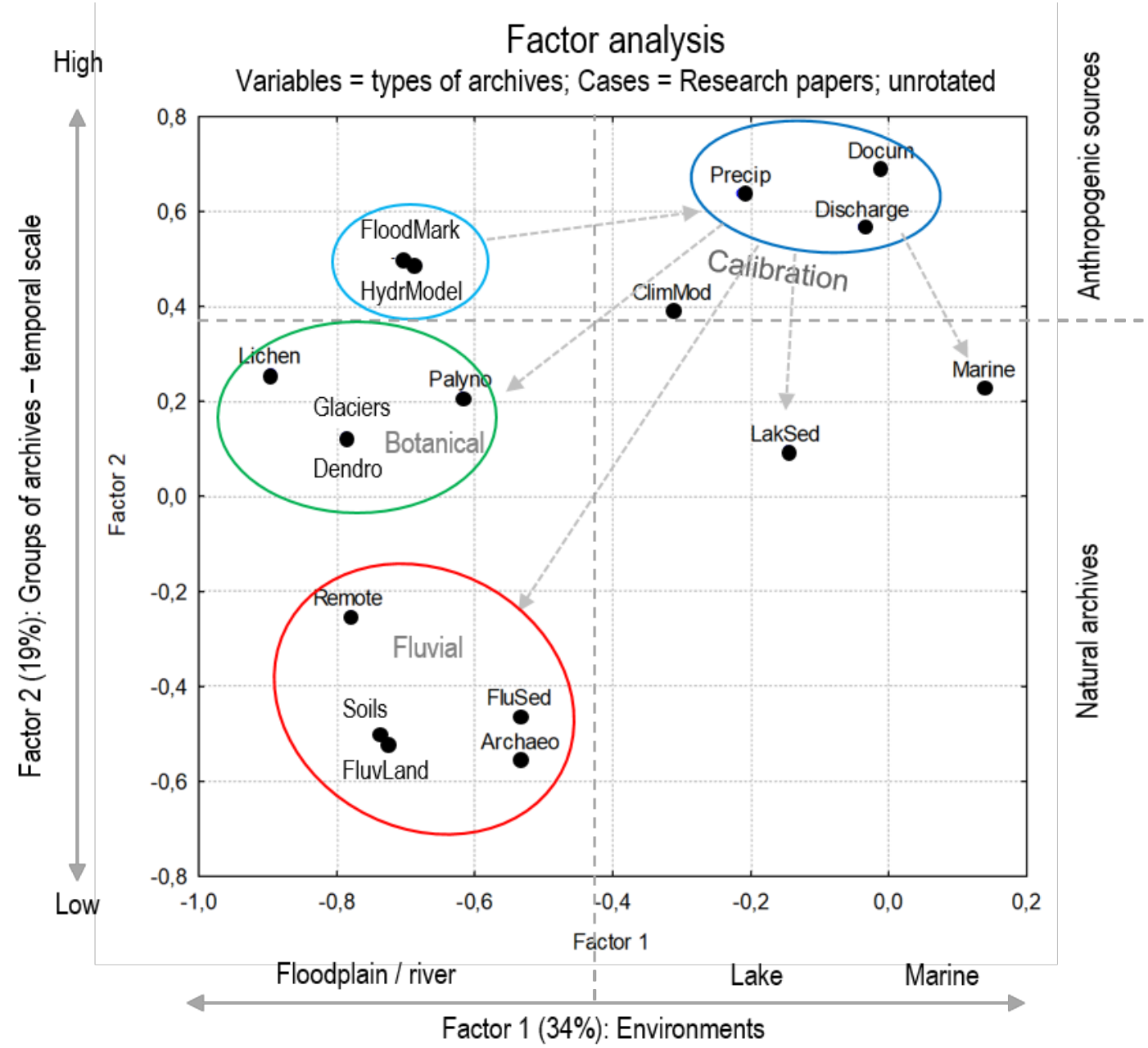

372 Figure 2: 2-D plot of the first two factors explaining the variability of types of archives analyzed by the research papers in this Special Issue.

375 The factor F1 is interpreted as the range of environments of natural flood 376 archives: floodplain and river environments show negative loadings, whereas 377 subaquatic (lakes and marine) archives show positive loadings. The second 378 factor reflects the temporal resolution of archives from low (millennial-scale 379 resolution of fluvial landforms and soils) to high (exact hour and/or day of river 380 discharge, documentary sources, flood marks and precipitation records). This 
381 distribution is similar to the 2-D plot (not shown) where temporal resolution (Table

3821 ) is included in the FA matrix as an additional binary variable. Another interesting outcome is the clear division (0.3 F2 loading) between natural archives and anthropogenic sources (Figure 2).

Our explanation for this variability is that high-resolution lake records are mostly calibrated against instrumental records of discharge and precipitation as well as documentary sources at annual and, in the best cases, seasonal resolution (Corella et al., this issue; Evin et al., this issue). Accurate calibration can also be applied in the studies of tree-rings and lichens. However, the botanical archives show a closer relationship with the group of fluvial archives, landforms, and soils because they are also used when dating flood deposits, flood levels, and impacts (Schulte et al., this issue; Zaginaev et al., this issue).

Terrestrial archives such as fluvial landforms, deposits, soils, and archeological sites provide flood information at lower temporal resolution than e.g. lakes but they can explain the spatial scale of flooding more accurately (Agatova et al., this issue; Lombardo et al., this issue). With regard to the fluvial sediments in floodplains, the studies of Fuller et al. (this issue), Santisteban et al. (this issue) and Schulte et al. (this issue) demonstrate that fluvial deposition mirrors sensitively severe and medium-magnitude floods.

400

\section{Perspectives of the integration of paleoflood archives}

402 To understand the epistemic concepts of paleoflood research, the thematic relationships relationship between the 17 research papers of the Special Issue were explored. Factor analysis (FA) was performed from the binary matrix (chapter 3), where research papers are variables and flood archives analyzed by 


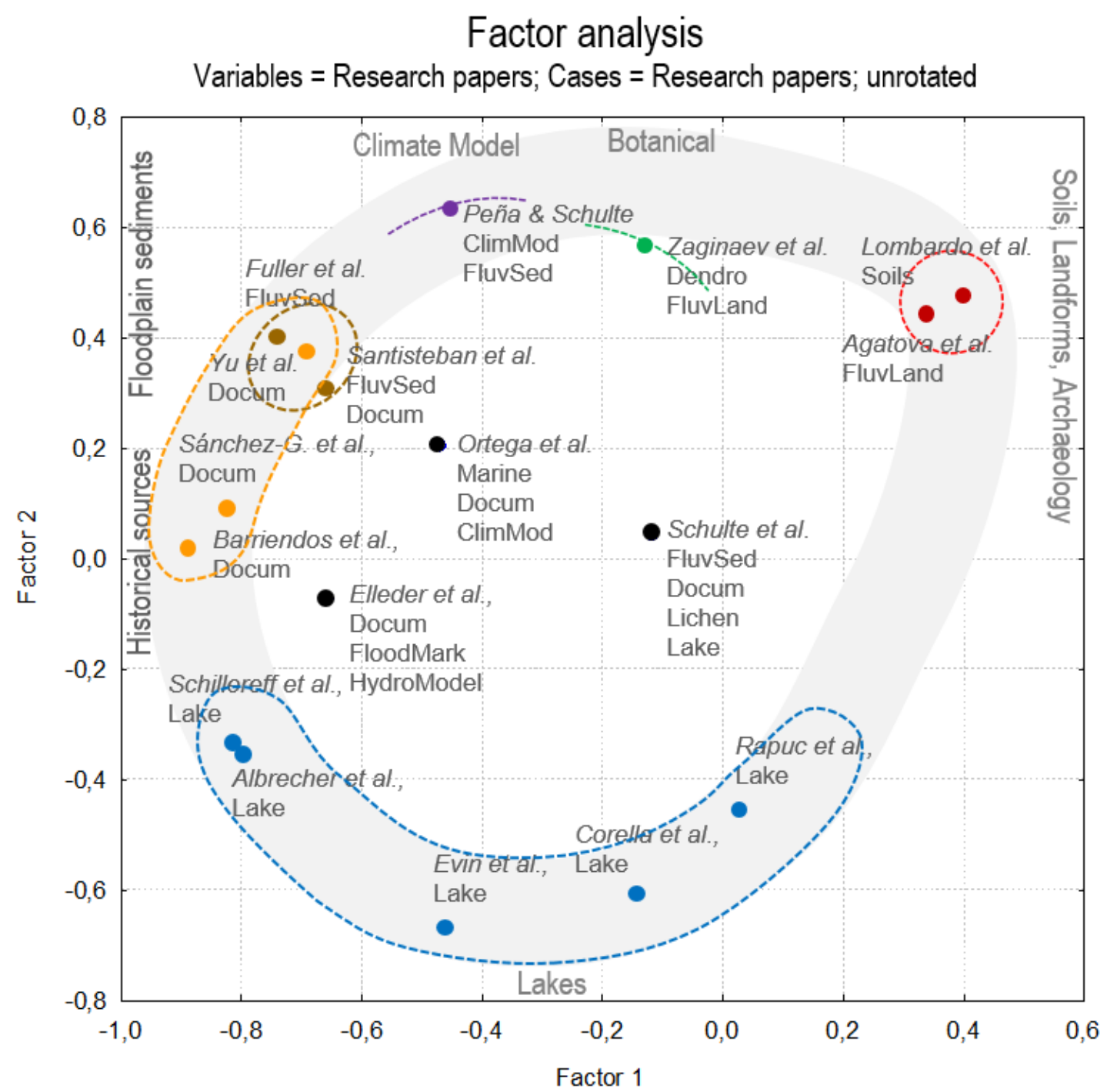

Factor 1

411 Figure 3: 2-D plot of the first two factors explaining the variations and associations of the 17 412 paleoflood approaches presented in the Special Issue. The matrix is defined by binary data of 413 analyzed types of archives. Below the references, the types of flood series generated by each 414 study are listed. Note that the number of generated flood series is lower than the total of flood 415 archives used for the compilation of flood series. 
417 The 2D-plot in figure 3 presents a very clear structure. Papers that used data

418 from 2 to 4 different types of flood archive are located around the periphery, essentially defining a circle (grey shading). Those papers which focus mainly on lake records are located at the bottom (negative loadings of F2). The different factor F1 loadings of these studies result from the fact that Schillereff et al. (this issue) and Albrecher et al. (this issue) compare their records with historical sources and instrumental discharges (also Evin et al., this issue), whereas Corella et al. (this issue) consider palynological data and Rapuc et al. (this issue) provide a calibration using precipitation records.

Papers that primarily explore historical sources of flood information (Barriendos et al., this issue; Sánchez-García et al., this issue; Yu et al., this issue) are situated on the left (strong negative loadings of F1) and show a close relationship to the studies of floodplain sediments (Fuller et al., this issue; Santisteban et al., this issue). This association arises from the fact that both types of archives documentary evidence of damage and flooding of settlements and infrastructure on one hand, and aggradation of overbank deposits, on the other - are sourced from similar areas of a catchment, e.g. in the floodplains of river valleys and deltas 434 (Schulte et al., this issue).

The loadings and associations of the only paper exclusively dedicated to paleoclimate modeling (Peña and Schulte, this issue; strong positive loading of F2) result from the fact that the flood periods of this model were inferred from geochemical floodplain proxies. The dendromorphological paper presented by Zaginaev et al. (this issue) is positioned a relatively short distance from the two papers dedicated to landforms, soils and archaeology (Lombardo et al., this issue; Agatova et al., this issue; positive loadings of F1 and F2), since trees were 
442 sampled on alluvial cones for the reconstruction of flash-floods and debris flow dynamics. The works of Agatova et al. (this issue) and Lombardo et al. (this issue) take slightly eccentric positions because these approaches are not strictly related to the analysis of flood records but rather on fluvial landscape and soil development.

447

Those papers that show the strongest degree of multi-disciplinary research and the highest number of integrated flood series are located in the center of the circle (Figure 3). Furthermore, they performed climatological or hydrological modeling. 450 In the case of the study of Elleder et al. (this issue), the authors analyzed one single flood episode reconstructing the propagation of the 1872 flooding by different documentary and instrumental archives. The study of Ortega et al. (this issue) focuses on marine, documentary and instrumental archives. Finally, the widest range of methodologies and archives are presented by the research 455 cluster of the Bernese Alps (Schulte et al., this issue), where fluvial, lake, 456 documentary and lichenometric flood series are integrated (Table 1).

457 Despite the rather modest number of cases (defined by the papers published in 458 this special issue), this factor analysis helps elucidate the different yet complementary approaches of palaeoflood research.

460 Thus, the distribution of papers and type of flood series (variables in Figure 3) were integrated into the conceptual model presented in Figure 4. 


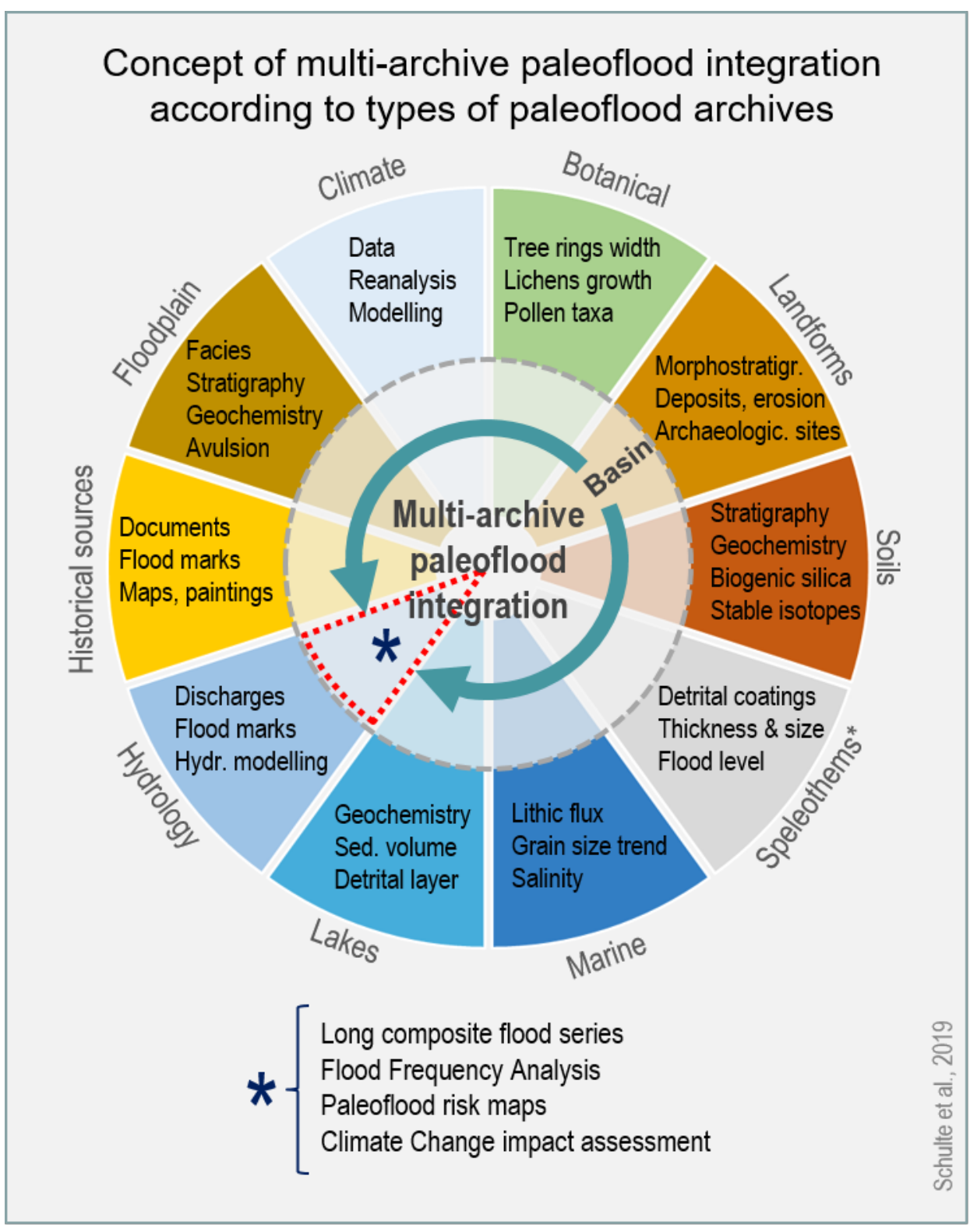

463

464 Figure 4: Concept of multi-archive paleoflood integration according to the type of flood archive.

465 The assembly of the type of flood series mirrors the distribution of papers and constructed flood series shown by the 2D-plot of the Factor Analysis of figure 3. Thus, the concept is not only based on a qualitative background but also on an empirical background inferred from the metadata of Table 1. Paleoflood records from speleothems* were not presented by any case study of the Special Issue, but they were included to complete the concept.

471 The conceptual model is structured in the form of a pie chart, in which each slice represents a type of paleoflood archive. Their arrangement is guided by their 
473 nature and statistical association (Figure 3). Furthermore, each slice assembles

474 the most commonly used paleoflood proxies or techniques applied to that type of archive. These archive types (external boundary of the chart) largely correspond to scientific disciplines focused on analyzing past floods. The (sub-) horizontal 477 slices in the middle (vertical order) represent terrestrial archives (geosphere), 478 including floodplains, soils, and landforms as well as historical sources. On top of 479 the geosphere are located botanical archives (biosphere) and climatological data series (atmosphere). Slices at the bottom of the conceptual model are associated with the hydrosphere and subaquatic archives: hydrological and hydraulic data from rivers, sedimentary and environmental archives from lakes and oceans and speleothem proxies from subsurface flooding.

All these flood archives can be integrated by means of statistical processing (inner circle) to compose synthetic regional flood records that reflect flooding up to basin-scale. At these points, it has to be stressed again that the combination of proxies (and archives) and their statistical processing are presented in Table 1 and Figures 2 and 3.

Finally, robust multi-archive flood records can provide accurate information for fundamental concerns of society (bottom of Figure 4):

i) Centennial and millennia-long flood calendars allow clusters of extreme events to be detected as well as changes in trends of flood frequency and magnitude during periods of changing cold/warm and dry/wet climate pulses and periods (Schulte et al., 2008, 2009a, 2015; Wilhelm et al., 2012);

ii) Flood Frequency Analyses (FFA) based on long time series of field evidence ("real flood evidence") of extreme floods can account for 
changes in the pattern of flooding during different climate conditions and cycles (i.e., non-stationarity; Knox, 2000; Mudelsee et al., 2003);

iii) Compiling spatial information of paleofloods in thematic maps contributes reduce uncertainties and help to identify unusual data in flood series. exceeded. 
522 Relatively few records of multi-millennial timescale (Fig. 5) are presented, and 523 they are all based on sedimentary reconstructions. Most long records show an 524 overall trend of increasing flood frequency/magnitude from ca. 4 to $5 \mathrm{ka} \mathrm{BP}$, with 525 some earlier episodes of high fluvial activity in Amazonia (before 8 ka BP; 526 Lombardo et al., this issue) and central Spain (from 8.5 to 7 ka BP; Santisteban 527 et al., this issue). Patterns of flooding around the world during the last five 528 millennia show more complexity, which could relate to: i) the higher temporal resolution of available archives; ii) the higher number of shorter flood records; iii)

530 the use of documentary sources and a wider range of natural archives spanning 531 the last millennium; and iv) the progressive intensification of human impact on the 532 landscape and river systems (Fig. 6). Flood regimes during the last few millennia are typically characterized by longer (many decades to centuries) periods of increased flood activity punctuated by short or abrupt drops in flood occurrence (e.g. 2.2 ka BP at site 3, $1.5 \mathrm{ka} \mathrm{BP}$ at site 5, $1.8 \mathrm{ka} \mathrm{BP}$ at site 11 and 12 in figure 5). However, it is important to note that these gaps do not occur synchronously 537 (Fig. 5).

Whereas flood activity increases through the mid-Holocene in most records, (i.e. Albrecher et al., this issue; Rapuc et al., this issue; Santisteban et al., this issue), 540 the picture of flood trends for the last 2500 years is much more diverse. Rapuc et al. (this issue) show an overall decrease in flooding activity while Albrecher et al.

542 (this issue), Ortega et al., (this issue) and Santisteban et al. (this issue) show an 543 increase until the last centuries. 


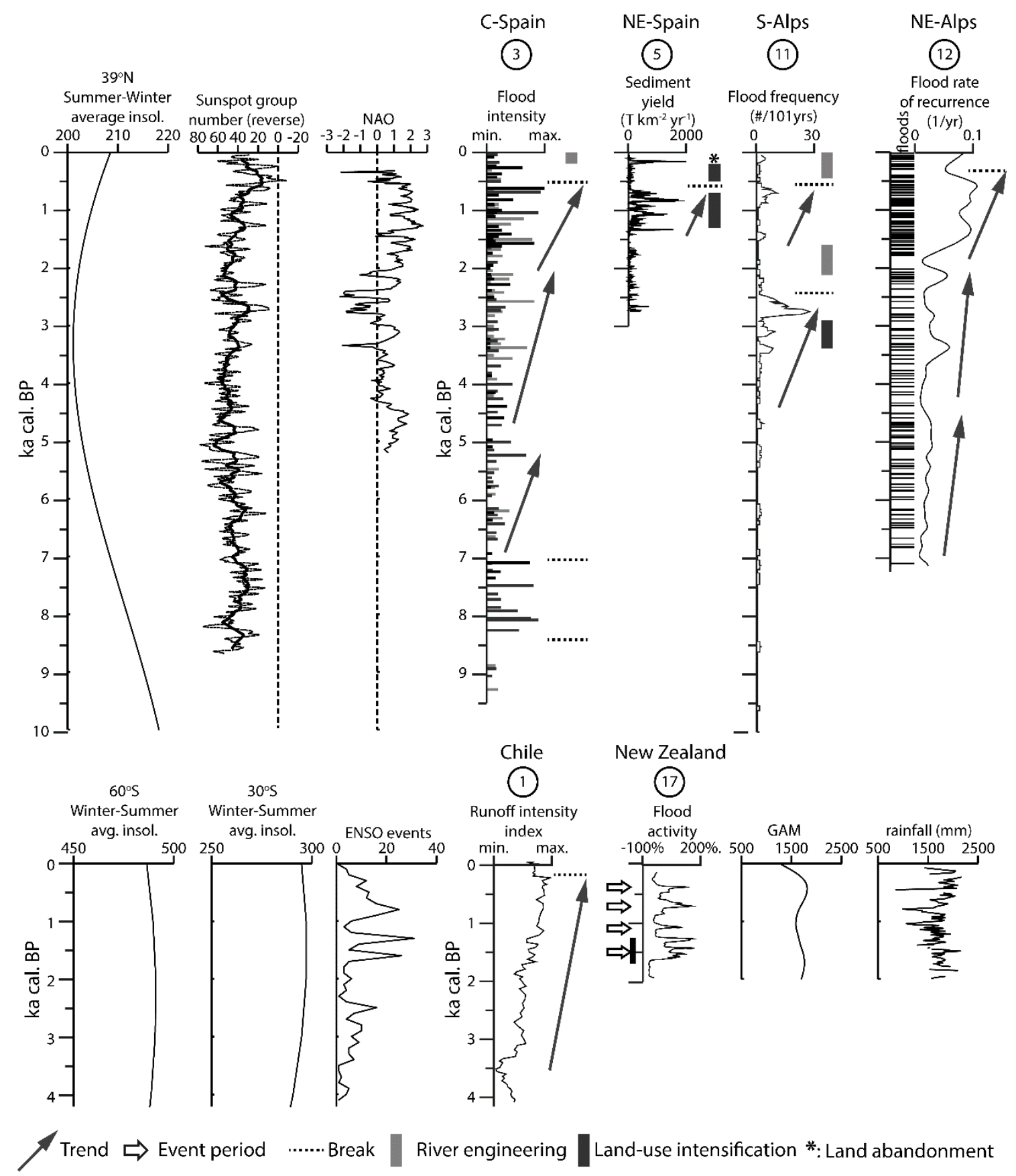

For (3):-Regional event - Sub-basin event - Local event

546 Figure 5.- Millennial-scale flooding episodes according to research papers in the Special Issue 547 and their relation to solar activity (sunspot group number and 21-points [210 years] moving 548 average: Wu et al., $2018 ; 39^{\circ} \mathrm{N}$ summer-winter difference calculated using the $\mathrm{R}$ package 549 'palinsol', Crucifix, 2016, using the calculations of Berger and Loutre, 1991) and NAO index (Olsen 550 et al., 2012) for European records and insolation at $60^{\circ} \mathrm{S}$ and $30^{\circ} \mathrm{S}$ (Berger and Loutre, 1991),

551 ENSO events (Moy et al., 2002) and ENSO-related GAM and rainfall episodes in subtropical 552 Australia (Barr et al., 2019) for the Pacific records. References of paleoflood studies: site $3=$ 
553 Santisteban et al. (this issue); site 5 = Corella et al. (this issue); site $11=$ Rapuc et al. (this issue);

554 site 12 = Albrecher et al. (this issue); site $1=$ Ortega et al. (this issue); site $17=$ Fuller et al. (this 555 issue).

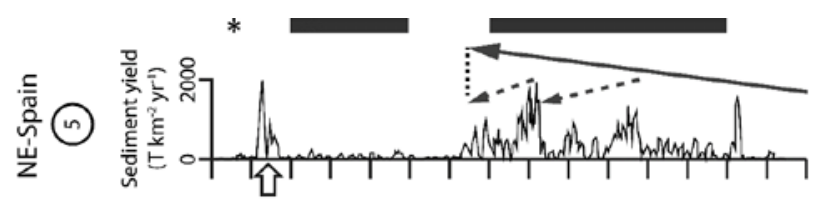

商(0)

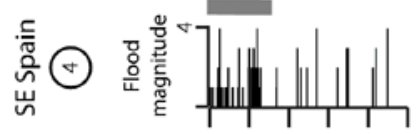

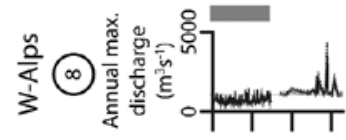

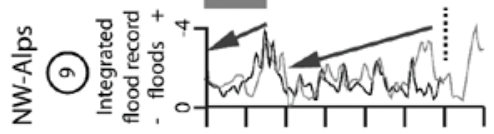

这

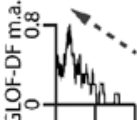

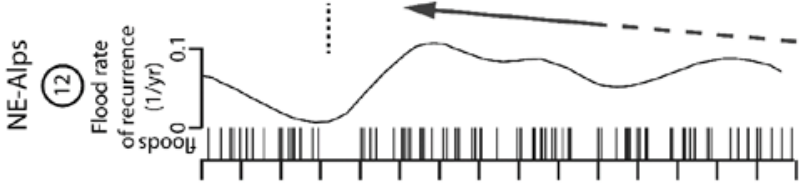
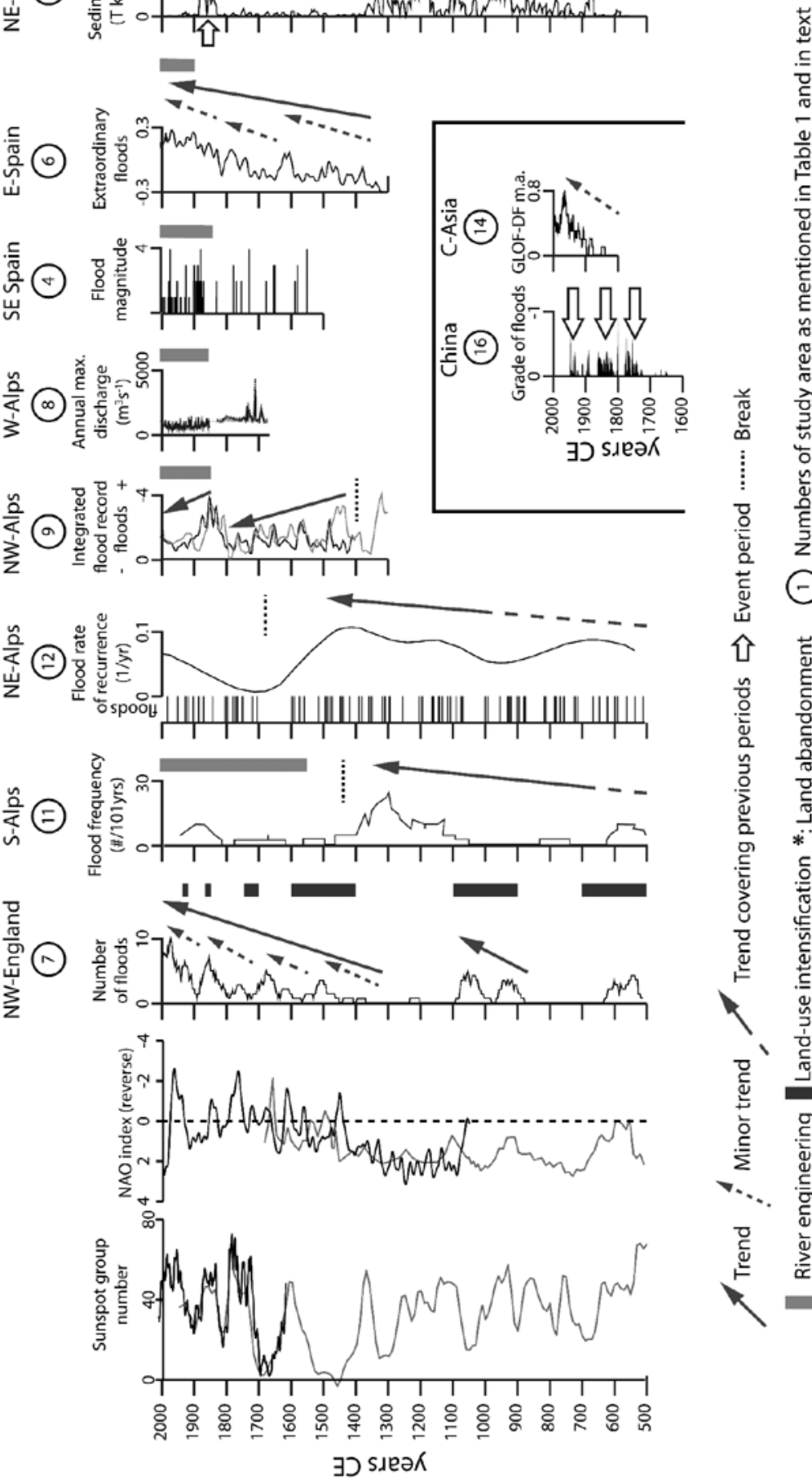

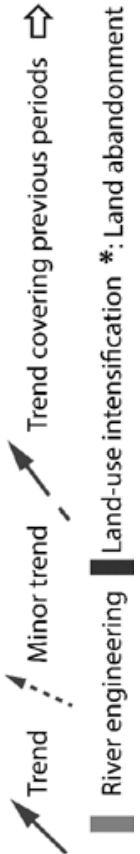


Figure 6.- European flood records spanning the last 2000 years, NAO (in reverse scale) (grey: Olsen et al., 2012; black: Trouet et al., 2009) and sunspot reconstructions (grey: Usoskin et al., 2014; black: WDC-SILSO, Royal Observatory of Belgium, Brussels http://sidc.be/silso/home). Similarities emerge in trends and periods of sunspot, NAO and flooding activity. There is a stronger link between NAO and flooding than at the millennial time-scale. References of paleoflood studies: site $7=$ Schillereff et al. (this issue); site $11=$ Rapuc et al. (this issue); site 12 = Albrecher et al. (this issue); site $9=$ Schulte et al. (this issue); site $8=$ Evin et al. (this issue); site 4 = Sánchez-Garcia et al. (this issue); site $6=$ Barriendos et al. (this issue); site $5=$ Corella et al. (this issue); site $16=$ Yu et al. (this issue); site $14=$ Zaginaev et al. (this issue).

Figure 6 presents ten data-rich paleoflood records that span the last $1.5 \mathrm{ka}$ and show similar variability (Fig. 6). Whilst most records show an increasing trend over this period, there are exceptions.

571 This heterogeneous pattern continues towards the present, when human action has become an increasingly important driver. Records showing sudden decreases (i.e. Corella et al., this issue; Ortega et al., this issue; Schulte et al., this issue) coincide at times with periods of increasing activity elsewhere (i.e. Barriendos et al., this issue; Schillereff et al., this issue; Zaginaev et al., this issue). These changes have been attributed by the authors to different natural forcings, depending on the period and timescale. For the millennial timescale, Rapuc et al. (this issue) and Santisteban et al. (this issue) relate the long-term trend to changes in insolation that could have affected seasonality and the persistence of atmospheric patterns (Fig. 5). Over shorter intervals, a number of regional ocean-atmosphere processes have been invoked as important natural forcings. Most presented studies for Europe relate flooding activity to negative NAO phases (e.g. Rapuc et al., this issue; Santisteban et al., this issue; Schillereff 
584

585

586

587

588

589

590

591

592

593

594

595

596

597

598

599

600

601

602

603

604

605

606

607

608

et al., this issue), (positive and negative) phases of summer NAO (Peña and Schulte, this issue; Schulte et al., this issue), changes in solar activity (Peña and Schulte, this issue; Schillereff et al., this issue) or cold phases linked to Atlantic multidecadal variations (Barriendos et al., this issue). For the Pacific domain, floods have been correlated to displacement of the westerlies/monsoon systems (Pacific Decadal Oscillation, PDO; Southern Annular Mode, SAM) and ENSO (Fuller et al., this issue; Ortega et al., this issue; Yu et al., this issue).

However, the frequency and intensity of flood events are the result of diverse and interacting factors operating at the local, regional and global scales. This produces complex records that are challenging to interpret. For example, Corella et al. (this issue) show a lake sediment record that responds to the seasonal distribution of storms and longer-term changes in soil properties (resulting from climate and land-use change).

The comparisons presented in Figures 5 and 6 (and in the papers mentioned) highlight that temporal correlations between regional forcings and flood reconstructions can rarely be drawn precisely. However, numerous studies in the Special Issue emphasis that the $19^{\text {th }}$ century - including the most recent cool climate pulses during the Little Ice Age - is a particularly flood-rich period (Barriendos et al., this issue; Rapuc et al., this issue; Schillereff et al., this issue; Sánchez-García et al., this issue; Yu et al., this issue) and the period with highest flood intensity in some regions (Corella et al., this issue; Schulte et al., this issue). This could be a consequence of synergetic effects between climate forcing and human factors (land-use, river management). With regard to the $20^{\text {th }}$ century, it is difficult to assess the influence of global warming because of intensifying social factors, the effect of hydraulic infrastructure and management, and demographic 
and urban growth (Barriendos et al., this issue; Sánchez-García et al., this issue).

610 Research drawing on historical sources might also be affected by the increased availability of flood information about smaller and moderate floods since the second half of the $19^{\text {th }}$ century. In addition, some flood types such as GLOFs and debris flows can be favored by particular physiographic settings like the formation of new glacier lakes in the Tien Shan mountains (Zaginaev et al., this issue). It is, however, noteworthy that 10 of the 14 papers displayed in Figures 5 and 6 do not record the $20^{\text {th }}$ century as the exceptional flood period.

Based on this synthesis of current research, palaeoflood data are optimally explored at decennial to centennial time scales (trends or periods). Finerresolution data are highly desirable but we must be conscious of multiple limiting factors. For example, the mixing depth of sedimentary records may limit data resolution. In addition, the timing of flooding in adjacent catchments can differ considerably, as shown by Schulte et al. (this issue) in the Bernese Alps, Santisteban et al. (this issue) in Central Spain and Barriendos et al. (this issue) in eighteen catchments of eastern Spain. This is unsurprising because hydrometeorological processes, sensitivity to climate variability or land-use change and thresholds may be site-specific. Palaeoflood research must account for this diversity. There are many potential pathways towards improvement: new chronological tools that circumvent technical limitations, such as ${ }^{14} \mathrm{C}$ plateaus/anomalies coupled to higher-resolution, multi-proxy studies, basin-scale studies, these need to be coupled with improved reconstructions of local factors, especially human activity, and climate forcing. For example, evaluating NAO or ENSO as a long-term flood driver is limited by the temporal resolution of NAO 
reconstructions. These requirements should guide future research and will be best achieved by expanding collaborative efforts.

\section{Human impact and disentangle anthropogenic from natural drivers}

Anthropogenic modifications to the landscape can dramatically alter flood regimes. Land-use change, in particular, the removal of mature vegetation covers and intensification of agriculture, destabilizes hillslopes and increases surface runoff and soil erosion potential (Dotterweich, 2008; Hoffmann et al., 2010). Structural interventions in rivers also affect the flood hazard (Schulte et al., 2015; Wetter et al. 2017; Munoz et al., 2018). Disentangling climatic and anthropogenic forcings in palaeoenvironmental data is a persistent challenge, however (Mills et al., 2017). Palaeoflood researchers are cognizant of these difficulties (Brisset et al., 2017; Wilhelm et al., 2019) and this set of papers presents an opportunity to explore current approaches and limitations when evaluating the human influence on long-term flood risk.

Some common approaches are evident, in general, but also in this Paleoflood Special Issue. There is common agreement that regional consistency across multiple proxies from independent archives denotes a climate signal whereas localized shifts probably point towards human disturbance (e.g. Barriendos et al., this issue; Fuller et al., this issue; Rapuc et al., this issue; Sánchez-García et al., this issue; Schulte et al., this issue). There is also evidence that interactive effects characterize the climate-human-flood nexus. For example, flood occurrence in northern Britain correlates with solar activity and NAO dynamics but concurrent woodland clearance for pastoralism appears to amplify flood frequency and magnitude (Schillereff et al., this issue). Similarly, Rapuc et al. (this issue) show 
658

659

660

661

662

663

664

665

666

667

668

669

670

671

672

673

674

675

676

677

678

679

680

681

a striking increase in flood frequency at Lake Iseo (Italy) around $3000 \mathrm{yr}$ BP that coincides with forest clearance indicators but lags the onset of climate-driven catchment erosion. Subsequent channel diversion, however, reduced sedimentation and discontinued the depositional flood record in some areas of lake basins (Rapuc et al., this issue) and floodplains (Carvalho and Schulte, 2013). Researchers must be aware that channelization can equally produce areas of aggradation and delta progradation (Schulte et al., 2009a; Wirth et al., 2011; Santisteban et al., this issue). Crucially, the effects of human pressure on flood regimes are often irregular through time. Corella et al. (this issue) infer from high-resolution, multi-proxy palaeoecological data that burning, grazing and cultivation triggered a prolonged period of frequent flooding around 700-1300 AD in northeast Spain. Equivalent activity during later centuries produced a more muted flood response, suggesting the system rebalanced to accommodate disturbance.

Hydraulic infrastructure also induces complex effects. Flood risk declined on Spanish rivers after expansive $20^{\text {th }}$-century dam building (Barriendos et al., this issue). Similarly, in several catchments of the Alps the combination of river correction and diversion into large alpine lakes lower peak downstream discharges because these lakes regulate flood waters like large retention areas (Wetter et al., 2011, Schulte et al., this issue). Conversely, channelization amplified flood magnitudes on the Mississippi (Munoz et al., 2018) while Elleder et al. (this issue) show the Mladotice dam collapse (Czech Republic) was a key factor behind the destructiveness of the 1872 flood. Sánchez-García et al. (this issue) note more recent dam construction, such as on the Almanzora River, Spain 
682 (Sánchez-García et al., this issue), has shifted the hydrometeorological baseline.

683 This hinders efforts to evaluate flood risk under $21^{\text {st }}$-century climatic warming.

684 This compilation of evidence stresses that the role of human activity as a flood 685 driver and proxy evidence used to characterize an anthropogenic signature must 686 be established on a site-by-site basis. This presents a number of challenges: first, 687 while the multi-proxy approach of Corella et al. (this issue) that distinguishes the 688 impacts of grazing, burning and cultivation is a powerful tool and Schulte et al. 689 (this issue) sift their synthesis of the European Alps for sites least affected by 690 human presence, such bountiful paleoflood data is rare. Second, we must keep 691 in mind that vegetation and fire dynamics can respond independently to climate so evidence of human-induced changes is crucial (Corella et al., this issue). Third, inter-site comparisons will widen chronological uncertainty. For example, most periods of frequent flooding in northern Britain (Schillereff et al., this issue) align with geomorphic evidence of hillslope destabilization across the region but both datasets depend on radiocarbon dates with multi-decadal uncertainties. Communicating the temporal uncertainty for comparator datasets should, therefore, be encouraged. Similarly, the approach of Rapuc et al. (this issue) to re-examine local archaeological evidence in a flooding context builds confidence in the time-transgressive role of human activity. Lastly, we must be wary of circular reasoning: catchment destabilization usually alters the rainfall-runoff relationship and soil erodibility. In this scenario, an anomalous lamination need not reflect a major flood because of modest rainfall on recently exposed, fragile soils could produce a similar signature. Mechanistic interpretations that consider transport capacity, for example, become crucial (Evin et al., this issue; Schillereff et al., this issue). Similarly, Corella et al. (this issue) convincingly attribute a shift 
707 in flood seasonality to human influence because known advancements in tilling practice would create the observed response. Site selection is also important. For example, Schulte et al. (this issue) show a divergent flood response on either flank of the Bernese Alps.

Isolating the anthropogenic component can be a formidable challenge. This collection of papers showcase how a coupled multi-archive, multi-proxy approach is imperative. In sedimentary systems, for example, do different geochemical proxies reflect rates of erosion and the carrying capacity of the system (grain size). Determining the nature of human modifications must also occur on a specific basis. Channel diversion and hillslope vegetation clearance may exert quite different effects on the flood regime. This could draw on archaeological evidence, for example (Rapuc et al., this issue). As human and climatic modifiers may coincide, less equivocal proxy evidence of human presence is needed. Indicator pollen (Corella et al., this issue) or pastoral DNA (Giguet-Covex et al., 2014) show real promise but may require deeper collaboration amongst international research groups in the future. Integrating sedimentary data with an independent archive, such as historical documents or tree rings would also be wise.

\section{Outlook: scoop and limitations of multi-archive paleoflood integration}

Taking a long-term perspective on flooding is fundamental for adequate hazard and risk assessment (e.g. flood-frequency analysis). The research papers in this Special Issue demonstrate that integrating field-data on "real" past floods derived from multiple historical and natural archives provides excellent flood data series. These datasets are uniquely positioned to document low-frequency, large- 
magnitude flood events that vary under different climate regimes (cooler, warmer and transitional climate periods) and/or environmental conditions (changes in land cover, land use, and river management).

However, reliable and accurate integration of paleoflood data relies on accounting for several critical issues:

i) Although this paper does not focus on the dating of flood records, we would like to stress first that considering dating uncertainties within the time series is vital prior to perform statistical analysis. The temporal resolution of records can vary significantly, however. Before flood data series from different natural and anthropogenic archives can be integrated into a regional model, a critical assessment of chronological models and homogenization of flood data is needed.

ii) The comparability of flood series from heterogeneous catchments and landscapes is often complex because the controlling factors and system sensitivity (e.g. of erosion or aggradation) to climatological conditions and hydrological extremes varies greatly across diverse hydrological and environmental settings.

iii) Indirect flood proxies recording climatic-environmental signals (e.g. sediments that are deposited by surface runoff in a small subcatchment) are different from records that are directly involved in the process of river flooding. Thus a precise understanding and a careful interpretation and/or calibration of physical processes are mandatory.

iv) Due to the heterogeneous natural response of different subsystems to flood drivers, not all flood series from a basin or a region can be integrated into a regional synthetic paleoflood master curve. The 
criteria for selection or rejection of individual flood series must not only follow statistical protocols but also consider process-based arguments. To identify "false alarms" and "missed" floods, data series should be tested against known regional hydrological extreme events that are documented by several records.

v) Human modification to many river systems has had major effects on the flood regime. These non-stationary conditions impose challenges when performing flood frequency analysis and evaluating flood risk under future climate change projections. Effort should be invested to isolate the anthropogenic component, ideally through a coupled multiarchive, multi-proxy approach.

vi) There is good evidence that some regional/global factors can systematically affect the dynamics of flooding over long timescales. There is now a need to achieve wider spatial and temporal coverage, leading to better understand the factors affecting intra-basin variability, especially interactions between natural and anthropogenic forcings.

When critical points i) - vi) are carefully taken into consideration, it seems clear that using a variety of paleoflood data from multiple archives and methodologies from different scientific fields is the best approach. Such multi-dimensional investigations can better account for limitations in individual records and more effectively analyze the spatial distribution (horizontal and vertical) of flood records in order to capture the physiographic and environmental diversity of a catchment. Schulte et al. (this issue) conclude from their integrated paleoflood pilot project in the Alps that such a multi-archive methodology can be applied in many regions. They do recommend, however, that this approach will be most effective in 
catchments where a high number of paleoflood records already exist and a profound understanding of the different flood proxies and flood generating mechanisms has been built up.

785 The meta-data of the case studies presented in this Special Issue in Table 1 suggest that paleoflood studies focused on fluvial depositional environments show a higher rate of integration with other types of paleoflood archive (mean of 4.5 types of archive) than studies focused on documentary sources (mean of 3.5) and lake sediments (mean of 2.4). We suggest that this adopted strategy of crosscorrelation is an effective method to compensate for the higher uncertainties of fluvial deposition in floodplains due to lower temporal sample resolution and possible effects of unconformities (possible gaps of flood information). The apparently more precisely dated lake and documentary flood records focus predominantly on instrumental calibration instead of multi-archive integration. However, several studies showed that neither of these series always record continuous flood information and they should be completed by other archives. In addition, spatial accuracy of flooding processes is a weak point of studies where flood information is obtained from single locations such as lakes, flood marks or settlements instead of larger flood-prone areas. In this latter case, terrestrial natural flood archives contribute highly valuable information.

Based on the gathered experience from the Special Issue, the activities of the work package WP2 and the FWG pilot multi-archive project, we suggest that over the next few years the agenda of regional paleoflood research might include the following trends:

i) Design of methodological approaches integrating paleoflood datasets through numerous regional pilot studies in different environments, 
ii) Improvements in flood frequency analysis and spatial flood risk assessment using multi-archive analysis, 


\section{Acknowledgments}

832 We would like to thank Fabienne Marret-Davies, Editor-in-Chief and responsible Home Editor of the Global and Planetary Change Journal, for her advice on how to focus and edit this Special Issue. We would also like to express our gratitude to the other Editors-in-Chief Zhengtang Guo, Alan Haywood, Liviu Matenco and the Editorial Board of this Journal for accepting our SI proposal. Thanks to Sunoj Sankaran and Yanping Hou from Elsevier for patiently managing and monitoring the editing and production processes. We are also grateful to a large number of reviewers of the 17 research papers for their expertise and judgment. The OSM conference session and the related Special Issue were supported by the Past Climate Changes Project (PAGES). We would like to thank in particular the unconditional support of Bruno Wilhelm and Juan Antonio Ballesteros Canovas, co-leaders with Lothar Schulte of the Flood Working Group (FWG), for incorporating this initiative into the agenda of the FWG community. The authors of this introductory paper and Guest Editors of this Special Issue are members of the Past Climate Change (PAGES) Floods Working Group 2016-2018 and 20192021.

848 The work was also co-funded by the Spanish Ministry of Economy and Competitivity (CGL2016-75475/R, CGL2011-30302-C02-01), the Catalan Institution for Research and Advanced Studies (ICREA Academia 2011).

\section{References}

Albrecher, H., Bladt, M., Kortschak, D., Prettenthaler, F., Swierczynski, T. Flood occurrence change-point analysis in the paleoflood record from Lake Mondsee (NE Alps). Global and Planetary Change [under review; this issue]. 
Agatova A.R., Nepop R.K., 2019. Pleistocene fluvial catastrophes in now arid NW areas of Mongolian Inland drainage basin. Global and Planetary Change 175, 211-225 [this issue].

Baker, V.R.,1987. Paleoflood hydrology and extreme flood events. Journal of Hydrology 96, 79-99.

Baker, V.R., 2006. Palaeoflood hydrology in a global context. Catena 66, 141-145.

Ballesteros-Cánovas, J.A., Márquez-Peñaranda, J.F., Sánchez-Silva, M., Díez-Herrero, A., Ruiz-Villanueva, V., Bodoque, J.M., \& Stoffel, M., 2014. Can tilted trees be used for palaeoflood discharge estimation? Journal of Hydrology, 529(2), 480489.

Barr, C., Tibby, J., Leng, M.J., Tyler, J.J., Henderson, A.C.G., Overpeck, J.T., Simpson, G.L., Cole, J.E., Phipps, S.J., Marshall, J.C., McGregor, G.B., 2019. Holocene el Niño-Southern Oscillation variability reflected in subtropical Australian precipitation. Scientific Reports, 9, 1627.

Barriendos, M., Ruiz-Bellet, J.L., Tuset, J., Mazón, J., Balasch, J. C., Pino, D., and Ayala, J. L. 2014. The "Prediflood" database of historical floods in Catalonia (NE Iberian Peninsula) AD 1035-2013, and its potential applications in flood analysis. Hydrol. Earth Syst. Sci., 18, 4807-4823.

Barriendos, M., Gil-Guirado, S., Pino, D., Tuset, J., Pérez-Morales, A., Alberola, A., Costa, J., Balasch, J.C., Castelltort, X.F., Mazon, J., Ruiz-Bellet, J.L. Flood events chronologies for Spanish Mediterranean coast from documentary sources (14th-20th centuries). Updated series for palaeoclimatic analysis and interaction with social factors [under review; this issue].

Benito, G., Lang, M., Barriendos, M., Llasat, M.C., Francés, F., Ouarda, T., Thorndycraft, V.R., Enzel, Y., Bardossy, A., Coeur, D. and Bobée, B., 2004. Use of systematic, palaeoflood and historical data for the improvement of flood risk estimation. Review of scientific methods. Natural Hazards, 31(3), 623-643.

Berger, A., Loutre. M.F., 1991. Insolation values for the climate of the last 10 million years. Quaternary Science Review, 10, 297-317.

Blöschl, G., Hall, J.L., Parajka, J., Perdigao, R.A.P., Merz, B., Arheimer, B., Aronica, G.T., Bilibashi, A., Bonacci, Q., Borga, M.,..., Živković N., 2017. Changing climate shifts timing of European floods. Science 2017, 357, 588-590.

Brázdil, R., Dobrovolný, P., Elleder, L., Kakos, V., Kotyza, O., Květoň, V., Macková, J., Müller, M., Štekl, J., Tolasz, R., Valášek, H., 2005a. Historical and Recent Floods 
in the Czech Republic. Masaryk University and Czech Hydrometeorological Institute, Brno, Prague, 370 pp.

Brázdil, R., Pfister, C., Wanner, H., von Storch, H., Luterbacher, J., 2005b. Historical climatology in Europe - the state of the art. Climatic Change 70 (3), 363-430.

Brisset, E., Guiter, F., Miramont, C., Troussier, T., Sabatier, P., Poher, Y., Cartier, R., Arnaud, F., Malet, E., Anthony, E.J., 2017. The overlooked human influence in historic and prehistoric floods in the European Alps. Geology 45, 347-350.

Carvalho, F., Schulte, L., 2013. Morphological control on sedimentation rates and patterns of delta floodplains in the Swiss Alps. Geomorphology, 198, 163-176.

Corella, J.P., Benito, G., Wilhelm, B., Montoya, E., Rull, V.,Vegas-Vilarrúbia, T., ValeroGarces, B.L. A millennium-long perspective of flood-related seasonal sediment yield in Mediterranean watersheds. Global and Planetary Change [under review; this issue].

Crucifix, M., 2016. palinsol: Insolation for Palaeoclimate Studies. R package version 0.93. https://CRAN.R-project.org/package=palinsol

D'Arrigo, R., Wilson, R., 2006. On the Asian Expression of the PDO. International Journal of Climatology, 26, 1607-1617.

Dotterweich, M., 2008. The history of soil erosion and fluvial deposits in small catchments of central Europe: Deciphering the long-term interaction between humans and the environment - A review. Geomorphology, 101, 192-208.

Elleder, L., 2015. Historical changes in frequency of extreme floods in Prague. Hydrol. Earth Syst. Sci., 19, 4307-4315.

Elleder, L., Krejčí, J., Racko, S., Daňhelka, J., Šírová, J., Kašpárek, L. Reliability check of flash-flood in Central Bohemia on May 25, 1872. Global and Planetary Change [under review; this issue].

Evin, G., Wilhelm, B., Jenny, J.-P., 2019. Flood hazard assessment of the Rhône River revisited with reconstructed discharges from lake sediments. Global and Planetary Change 172, 114-123 [this issue].

Denniston, R.F., Luetscher, M., 2017. Speleothems as high-resolution paleoflood archives. Quaternary Science Reviews, 170, 1-13.

Díez-Herrero, A., Ballesteros, J.A., Ruiz-Villanueva, V., Bodoque, J.M., 2013. A review of dendrogeomorphological research applied to flood risk analysis in Spain Geomorphology 196, 211-220. 
Geoportal des Kanton Bern, 2018. Naturgefahren-Ereigniskataster. Several maps online. Amt für Geoinformationen des Kantons Bern [Natural Hazard Event Cadastral. Division of Geoinformation of the Canton Berne] https://www.geo.apps.be.ch/de; last access 15/03/2019.

Giguet-Covex, C., Pansu, J., Arnaud, F., Rey, P.-J., Griggo, C., Gielly, L., Domaizon, I., Coissac, E., David, F., Choler, P., Poulenard, J., Taberlet, P., 2014. Long livestock farming history and human landscape shaping revealed by lake sediment DNA. Nature Communications 5, 3211.

Glaser, R., 2001. Klimageschichte Mitteleuropas. 1000 Jahre Wetter, Klima, Katastrophen, Wissenschaftliche Buchgesellschaft Darmstadt, Darmstadt, $227 \mathrm{pp}$.

Fuller, I., Macklin, M., Toonen, W., Turner, J., Norton, K. A 2000 year record of palaeofloods in a volcanically-reset catchment: Whanganui River, New Zealand. Global and Planetary Change [under review; this issue].

Hoffmann, T., Thorndycraft, V.R., Brown, A.G., Coulthard, T.J., Damnati, B., Kale, V.S., Middelkoop, H., Notebaert, B., Walling, D.E., 2010. Human impact on fluvial regimes and sediment flux during the Holocene: Review and future research agenda. Global Planetary Change 72, 87-98.

Kiss, A., 2009. Floods and weather in 1342 and 1343 in the Carpathian basin, J. Environ. Geogr., 2, 37-47.

Knox, J.C., 2000. Sensitivity of modern and Holocene floods to climate change. Quaternary Science Reviews 19, 439-457.

Lombardo, U., Ruiz-Pérez, J., Rodrigues, L., Mestrot, A., Mayle, F., Madella, M., Szidat, S., Veit, H., 2019. Holocene land cover change in south-western Amazonia inferred from paleoflood archives. Global and Planetary Change 174, 105-114 [this issue].

Macdonald, N., Sangster, H., 2017. High-magnitude flooding across Britain since AD 1750. Hydrology Earth System Sciences, 21, 1631-1650.

Mills, K., Schillereff, D., Saulnier-Talbot, É., Gell, P., Anderson, N.J., Arnaud, F., Dong, X., Jones, M., McGowan, S., Massaferro, J., Moorhouse, H., Perez, L., Ryves, D.B., 2017. Deciphering long-term records of natural variability and human impact as recorded in lake sediments: a palaeolimnological puzzle. Wiley Interdisciplinary Reviews: Water 4, e1195. 
Moy, C.M., Seltzer, G.O., Seltzer, D.T., Anderson, D.M., 2002. Variability of El Nino/Southern Oscillation activity at millennial time scales during the Holocene epoch. Nature, 420, 162-165.

Mudelsee, M., Börngen, M., Tetzlaff, G., \& Grünewald, U., 2003. No upward trends in the occurrence of extreme floods in central Europe. Nature, 425, 166-169.

Munoz, S. E., Giosan, L., Therrell, M. D., Remo, J. W. F., Shen, Z., Sullivan, R. M., Wiman, C., O’Donnell, M., Donnelly, J. P., 2018. Climatic control of Mississippi River flood hazard amplified by river engineering. Nature, 556(7699), 95-98.

Olsen, J., Anderson, N.J., Knudsen, M.F. 2012. Variability of the North Atlantic Oscillation over the past 5,200 years. Nature Geoscience, 5, 808-812.

Ortega, C., Vargas, G., Rojas, M., Rutllant, Muñoz, P., Lange, C.B., Pantoja, S., Dezileau, L., Ortlieb, L., 2019. Extreme ENSO-driven torrential rainfalls at the southern edge of the Atacama Desert during the Late Holocene and their projection into the $21^{\text {th }}$. Century Global and Planetary Change $175,226-237$ [this issue].

PAGES - Floods Working Group, 2017. For an improvement of our flood knowledge through paleodata. White paper of the PAGES - Floods Working Group, Grenoble, 15 pp. http://www.pages-igbp.org/ini/wg/floods/intro

Paprotny, D., Sebastian, A., Morales-Nápoles, O., N. Jonkman, S.N., 2018. Trends in flood losses in Europe over the past 150 years. Nature Communications (2018) 9:1985, DOI: 10.1038/s41467-018-04253-1

Peña, J.C., Schulte, L. A paleoclimate model of the atmospheric variability related to large summer floods in the Hasli-Aare (Swiss, Alps) from the AD 1300 to 2010. Global and Planetary Change [under review; this issue].

Pfister, C., 1999. Wetternachhersage. 500 Jahre Klimavariationen und Naturkatastrophen (1496-1995), Haupt-Verl., Bern, 304 pp.

Rapuc, W., Sabatier, P., Arnaud, F., Palumbo, A., Develle, A.-L., Reyss, J.-L., Augustin, L., Régnier, E., Piccin, A., Chapron, E., Dumoulin, J.-P., Grafenstein, U.v., 2019. Holocene-long record of flood frequency in the Southern Alps (Lake Iseo, Italy) under human and climate forcing. Global and Planetary Change 175, 160-172 [this issue].

Röthlisberger, G., 1991. Chronik der Unwetterschäden in der Schweiz. WSL Bericht 330, Eidgenössische Forschungsanstalt für Wald, Schnee und Landschaft, Birmensdorf, $122 \mathrm{pp}$. 
1019

1020

1021

1022

Sánchez-García, C., Schulte, L., Carvalho, F., Peña, J.C. 500-year flood history in the arid environments of south-eastern Spain. The case of the Almanzora River. Global and Planetary Change [under review; this issue].

Santisteban, J.I., Mediavilla, R., Celis, A., Castaño, S., de la Losa, A., 2017. Millennialscale cycles of aridity as a driver of human occupancy in central Spain? Quaternary International 407,96-109.

Santisteban, J.I., Mediavilla, R., Galán de Frutos, L., López Cilla, I. Holocene floods in a complex fluvial wetland in central Spain: environmental variability, climate and time. Global and Planetary Change [under review; this issue].

Schillereff, D.N., Chiverrell, R.C., Macdonald, N., Hooke, J.M., 2014. Flood stratigraphies in lake sediments: A review. Earth-Science Reviews 135, 17-37.

Schillereff, D.N., Chiverrell, R.C., Macdonald, N. and Hooke, J.M., 2016. Hydrological thresholds and basin control over paleoflood records in lakes. Geology, 44(1), 43-46.

Schillereff, D., Chiverrell, R., Macdonald, N., Hooke, J., Welsh, K., Piliposian, G., Croudace, I. Convergent human and climate forcing of late-Holocene flooding in northwest England. Global and Planetary Change [under review; this issue].

Schmocker-Fackel, P. Naef, F., 2010b. Changes in flood frequencies in Switzerland since 1500. Hydrol. Earth Syst. Sci., 14, 1581-1594.

Schulte, L., Julià, R., Oliva, M., Burjachs, F., Veit, H., Carvalho, F., 2008. Sensitivity of Alpine fluvial environments in the Swiss Alps to climate forcing during the Late Holocene. Sediment Dynamics in Changing Environments, IAHS Publ. 325, 367374.

Schulte, L., Veit, H., Burjachs, F., Julià, R., 2009a. Lütschine fan delta response to climate variability and land use in the Bernese Alps during the last 2400 years. Geomorphology, 108, 107-121.

Schulte, L., Julià, R., Veit, H., Carvalho, F., 2009b. Do high-resolution fan delta records provide a useful tool for hazard assessment in mountain regions? International Journal of Climate Change Strategies and Management, 2, 197-210.

Schulte, L., Peña, J.C., Carvalho, F., Schmidt, T., Julià, R., Llorca, J., Veit, H., 2015. A 2600-year history of floods in the Bernese Alps, Switzerland: frequencies, mechanisms and climate forcing. Hydrology and Earth System Sciences 19, 3047-3072. 
Schulte, L., Mudelsee, M., St George, S., Peña, J.C., 2017. Work Package WP2: Integrating and analyzing paleoflood data. In, PAGES Floods Working Group. For an improvement of our flood knowledge through paleodata. White paper of the PAGES - Floods Working Group, Grenoble, 11-14 pp. http://www.pagesigbp.org/ini/wg/floods/intro

Schulte, L., Wetter, O., Wilhelm, B., Peña, J.C., Amann, B., Wirth, S.B., Carvalho, F., Gómez-Bolea, A. Integration of multi-archive datasets towards the development of a four-dimensional paleoflood model in alpine catchments. Global and Planetary Change [under review; this issue].

Trouet, V., Esper, J., Graham, N.E., Baker, A., Scourse, J.D., Frank, D.C., 2009. Persistent Positive North Atlantic Oscillation Mode Dominated the Medieval Climate Anomaly. Science, 324, 78-80.

UNISDR, 2015. Making Development Sustainable: The Future of Disaster Risk Management. Global Assessment Report on Disaster Risk Reduction. Geneva, Switzerland: United Nations Office for Disaster Risk Reduction (UNISDR), $314 \mathrm{pp}$.

Usoskin, I.G., Hulot, G., Gallet, Y., Roth, R., Licht, A., Joos, F., Kovaltsov, G.A., Thébault, E., Khokhlov, A., 2014. Evidence for distinct modes of solar activity. Astronomy \& Astrophysics, 562, L10. https://doi.org/10.1051/0004-6361/201423391

Wetter, O., 2017. The potential of historical hydrology in Switzerland. Hydrology and Earth System Sciences 21(11), 5781-5803.

Wetter, O., Pfister, C., Weingartner, R., Luterbacher, J., Reist, T., Trösch, J., 2011. The largest floods in the High Rhine basin since 1268 assessed from documentary and instrumental evidence. Hydrological Sciences Journal 56 (5), 733-758.

Wilhelm, B., Arnaud, F., Sabatier, P., Crouzet, C., Brisset, E., Chaumillon, E., Disnar J.R., Guiter, F., Malet, E., Reyss, J.-L., Tachikawa, K., Bard, E., Delannoy, J.J., 2012. 1400 years of extreme precipitation patterns over the Mediterranean French Alps and possible forcing mechanisms. Quaternary Research 78(1), 112.

Wilhelm B., Ballesteros Canovas J.A., Macdonald N., Toonen W., Baker V., Barriendos M., Benito G., Brauer A., Corella Aznar J.P., Denniston R., Glaser R., Ionita M., Kahle M., Liu T., Luetscher M., Macklin M., Mudelsee M., Munoz S., Schulte L., St George S., Stoffel M., Wetter O., 2019. Interpreting historical, botanical, and geological evidence to aid preparations for future floods. WIREs Water. 2019;6:e1318. 
1058

1059

1060

1061

1062

1063

1064

1065

1066

1067

1068

1069

1070

1071

1072

1073

Wirth, S.B., Girardclos, S., Rellstab, C., Anselmetti, F.S., 2011. The sedimentary response to a pioneer geo-engineering project: Tracking the Kander River deviation in the sediments of Lake Thun (Switzerland). Sedimentology 58, 17371761.

Wirth, S.B., Glur, L., Gilli, A., Anselmetti, F.S., 2013. Holocene flood frequency across the Central Alps - solar forcing and evidence for variations in North Atlantic atmospheric circulation, Quaternary Science Reviews 80, 112-128.

Wu, C.J., Krivova, N.A., Solanki, S.K., Usoskin, I.G., 2018. Solar total and spectral irradiance reconstruction over the last 9000 years. Astronomy \& Astrophysics, 620, A120. https://doi.org/10.1051/0004-6361/201832956

Yu, X., Wang, Y., Kang, Z., Yu, S. Synchronous droughts and floods in Southern Chinese Loess Plateau in phase with decadal solar activities [under review; this issue].

Zaginaev, V., Petrakov, D., Erokhin, S., Meleshko, A., Stoffel, M., Ballesteros-Cánovas, J.A., 2019. Geomorphic control on regional glacier lake outburst flood and debris flow activity over northern Tien Shan. Global and Planetary Change 176 (2019) 50-59 [this issue]. 